\title{
Influence of Cultivation Conditions on the Production of Staphylocoagulase by Staphylococcus aureus 104
}

\author{
By W. ENGELS, M. KAMPS AND C. P. A. VAN BOVEN \\ Department of Medical Microbiology, State University of Limburg, \\ P.O. Box 616, Maastricht, The Netherlands
}

(Received 29 March 1978; revised 11 June 1978)

\begin{abstract}
High yields of staphylocoagulase from Staphylococcus aureus 104 were obtained in a simple salts medium supplemented with glycerol, casein hydrolysate and three vitamins. Conditions of oxygen-limitation (dissolved oxygen concentration $\ll 2 \%$ ), a pH of $7 \cdot 4$, a temperature of $35^{\circ} \mathrm{C}$ and a 1 in 10 inoculum of overnight culture were required for optimal yields of staphylocoagulase.
\end{abstract}

\section{INTRODUCTION}

Staphylocoagulase is an extracellular protein produced by potentially pathogenic strains of Staphylococcus aureus. However, its precise role in the pathogenesis of infections due to $S$. aureus is not clear.

Several reports describe the partial purification of staphylocoagulase, but none of these preparations were of sufficient homogeneity to assess the mode of action of the enzyme (Blobel et al., 1960; Duthie \& Haughton, 1958; Jacherts, 1956; Jeljaszewicz, 1958; Murray \& Ghodes, 1960; Siwecka \& Jeljaszewicz, 1968; Soulier et al., 1967; Stutzenberger \& San Clemente, 1968; Tager, 1948; Zolli \& San Clemente, 1963). Bas et al. (1974) found that purified staphylocoagulase was a single-chain protein with a molecular weight of 61000 , an isoelectric point at $\mathrm{pH} \mathrm{4.53}$ and with aspartic acid as the N-terminal amino acid. Hemker et al. (1975) reported that the activation of human prothrombin by staphylocoagulase occurred stoicheiometrically, one molecule of staphylocoagulase forming a complex with one of prothrombin without splitting the peptide bonds. Therefore the thrombin activity of this complex was probably not due to proteolytic breakdown of prothrombin to thrombin, but to a change of the tertiary structure of prothrombin that unmasked a thrombin-like active centre.

Various authors have described different conditions for optimal production of staphylocoagulase, presumably due to variations in strains, media and cultivation conditions. Therefore a new investigation was undertaken to assess the effects of medium composition and environmental factors on the formation of staphylocoagulase by $S$. aureus 104 when grown in batch cultures. This strain was chosen because high yields of enzyme had been obtained with it (Bas et al., 1974; Soulier et al., 1967).

\section{METHODS}

Bacterial strains. Staphylococcus aureus 104 (after Tager) was kindly provided by Dr J. P. Soulier (Centre National de Transfusion Sanguine, Paris). Staphylococcus aureus NCTC 8178 was from the National Collection of Type Cultures, London. Stock cultures were maintained on nutrient agar slants at $4{ }^{\circ} \mathrm{C}$ and were subcultured monthly.

Cultivation media. Brain Heart Infusion (Difco) contained $37 \mathrm{mg} \mathrm{ml}^{-1}$. Yeast extract medium contained a simple salts mixture described by Evans et al. (1970) (omitting $\mathrm{NH}_{4} \mathrm{Cl}$ ) with a $\mathrm{Mg}^{2+}$ concentration of $100 \mu \mathrm{M}$, 


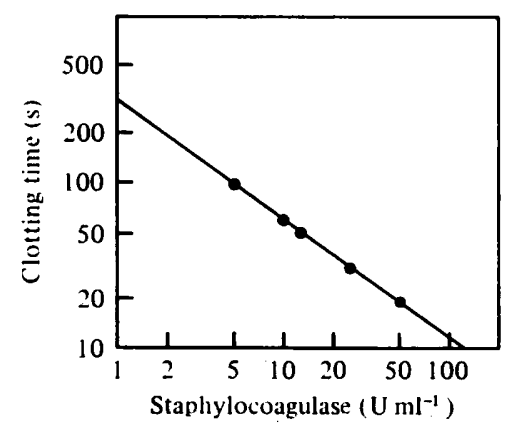

Fig. 1. Relation between clotting time and activity of crude staphylocoagulase.

supplemented with (per $\mathrm{ml}$ ) $1 \mathrm{mg}$ glycerol and $20 \mathrm{mg}$ yeast extract (Difco). Casein hydrolysate medium contained the simple salts mixture of Evans et al. (1970) (omitting $\mathrm{NH}_{4} \mathrm{Cl}$ ) with a $\mathrm{Mg}^{2+}$ concentration of $100 \mu \mathrm{M}$, supplemented with (per ml) $20 \mathrm{mg}$ Casamino acids (Difco), $1 \mathrm{mg}$ glycerol and $20 \mu \mathrm{l}$ vitamin solution. Synthetic medium contained the simple salts mixture of Evans et al. (1970) with a $\mathbf{M g}^{2+}$ concentration of $100 \mu \mathrm{M}$, supplemented with (per ml) $1 \mathrm{mg}$ glycerol, $20 \mu \mathrm{l}$ vitamin solution and the following amino acids (mg) : L-Asp, 0.76; L-Thr, 0.64; L-Ser, 1.12; L-Glu, 2.28; L-Pro, 0.32; L-Gly, 0.32; L-Ala, 1.16; L-(Cys) 2 , 0.16; L-Val, 1.04; L-Met, 0.32; L-Ile, 0.84; L-Leu, 1.32; L-Tyr, 0.44; L-Phe, 1.36; L-Lys, 1.66; L-His, 0.28; L-Try, $0.20 ; \mathrm{L}-\mathrm{Arg}, 0.68$. The vitamin solution contained (per ml double glass-distilled water) $300 \mu \mathrm{g}$ thiamin, $100 \mu \mathrm{g}$ nicotinic acid and $30 \mathrm{ng}$ biotin. This mixture was heat sterilized separately at pH $4 \cdot 5$. The pH of all media was adjusted to $7 \cdot 4$.

Cultivation methods. Staphylococcus aureus 104 was cultivated in 20 ml medium in $100 \mathrm{ml}$ Erlenmeyer flasks at $35^{\circ} \mathrm{C}$. Some cultures were shaken in a gyrotary waterbath (G-76, New Brunswick) at $190 \mathrm{rev} . \mathrm{min}^{-1}$ and a displacement of $13 \mathrm{~mm}$. The aeration efficiency in the shaken flasks, as determined by the sulphite oxidation method (Cooper et al., 1944), was less than $5 \mathrm{mmol} \mathrm{O}_{2} \mathrm{l}^{-1} \mathrm{~h}^{-1}$.

The organism was also cultivated in stirred fermenters (Bioflo C30, New Brunswick), with a culture volume of 300 to $400 \mathrm{ml}$, depending on the stirrer speed. No baffles were used. Air was flushed over the culture surface at a rate of $300 \mathrm{ml} \mathrm{min}^{-1}$. The aeration efficiency, determined by the sulphite oxidation method (Cooper et al., 1944), was less than $5 \mathrm{mmol} \mathrm{O}_{2} \mathrm{l}^{-1} \mathrm{~h}^{-1}$ at stirrer speeds lower than $400 \mathrm{rev}$. $\mathrm{min}^{-1}$. The dissolved oxygen concentration was less than $2 \%$ at speeds lower than $400 \mathrm{rev}$. $\mathrm{min}^{-1}$. The pH was maintained constant at 7.4 by automatic addition of $2 \mathrm{M}-\mathrm{KOH}$. The temperature was held at $35^{\circ} \mathrm{C}$.

Staphylocoagulase assay. The staphylocoagulase activity was determined on the basis of the clotting time obtained when $0 \cdot 1 \mathrm{ml}$ culture supernatant $(1 \mathrm{ml}$ culture was centrifuged at $12500 \mathrm{~g}$ for $2 \mathrm{~min})$ was mixed with $0.1 \mathrm{ml}$ rabbit plasma and incubated at $37^{\circ} \mathrm{C}$ (Soulier et al., 1967). The amount of staphylocoagulase was calculated from a reference curve constructed from clotting times obtained with dilutions (in Michaelis buffer) of a pool of 10 crude staphylocoagulase preparations. This pool was considered to contain 1000 arbitrary units (U) $\mathrm{ml}^{-1}$ (Fig. 1).

Preparation of crude staphylocoagulase. Crude staphylocoagulase was prepared by a modification of the method described by Soulier et al. (1967). Staphylococcus aureus 104 was cultivated in $40 \mathrm{ml}$ casein hydrolysate medium in $200 \mathrm{ml}$ Erlenmeyer flasks at $35^{\circ} \mathrm{C}$ without shaking. After $24 \mathrm{~h}$ the cultures were centrifuged for $30 \mathrm{~min}$ at $15380 \mathrm{~g}$; the supernatant was brought to $\mathrm{pH} 3.5$ with $3 \mathrm{M}-\mathrm{HCl}$ and left for $18 \mathrm{~h}$ at $0{ }^{\circ} \mathrm{C}$. The precipitate was collected by centrifugation for $30 \mathrm{~min}$ at $7000 \mathrm{~g}$, washed once with $0.15 \mathrm{M}$-sodium acetate buffer (pH 3.8), dissolved in $0.15 \mathrm{M}-\mathrm{NaCl}$ and brought to $\mathrm{pH} 7 \cdot 4$ with $\mathrm{NaOH}$.

Staphylocoagulase production is defined here as net production, i.e. the enzyme synthesized by some or all of the bacterial cells plus its release from the living or dead cells minus any inhibition or destruction outside the cell.

\section{RESULTS AND DISCUSSION}

To simplify the procedure for purification of staphylocoagulase produced by $S$. aureus 104 , it was necessary to replace the Brain Heart Infusion medium that is generally used by a more defined medium. The major disadvantage of Brain Heart Infusion is its high lipid content that necessitates a very time-consuming lipid-extraction step in the purification procedure (Bas et al., 1974).

The amounts of staphylocoagulase produced in various media are shown in Table 1. The 
Table 1. Staphylocoagulase production by Staphylococcus aureus 104 in various media

Erlenmeyer flasks $(100 \mathrm{ml})$ containing $20 \mathrm{ml}$ medium were inoculated with $2 \mathrm{ml}$ overnight culture and cultivated at $35^{\circ} \mathrm{C}$ without shaking or with shaking at $190 \mathrm{rev}$. min ${ }^{-1}$. After $18 \mathrm{~h}$, staphylocoagulase and absorbance at $540 \mathrm{~nm}$ (figures in parentheses) were determined.

\begin{tabular}{lcc}
\multicolumn{1}{c}{ Medium } & \multicolumn{1}{c}{ Staphylocoagulase $\left(\mathrm{U} \mathrm{ml}^{-1}\right)$} \\
\cline { 2 - 3 } Brain Heart Infusion & $13(6 \cdot 29)$ & Shaken culture \\
Yeast extract medium & $21(4 \cdot 24)$ & $24(11 \cdot 69)$ \\
Casein hydrolysate medium & $65(4 \cdot 73)$ & $17(11 \cdot 75)$ \\
Casein hydrolysate (vitamin-free) medium & $10(5 \cdot 05)$ & $<1(8 \cdot 77)$ \\
Synthetic medium & $42(6.53)$ & $5(9 \cdot 68)$
\end{tabular}

shaken cultures, except those in Brain Heart Infusion, produced less staphylocoagulase than did the static cultures. Several authors (Duthie \& Haughton, 1958; Fahlberg \& Marston, 1960; Stutzenberger \& San Clemente, 1968; Tager, 1948) have reported that agitation is essential for the production of large amounts of staphylocoagulase. Soulier et al. (1967) found that static cultures of $S$. aureus 104 in Brain Heart Infusion produced $15 \mathrm{U} \mathrm{ml}^{-1}$ (11 Roux bottles containing $200 \mathrm{ml}$ medium).

The reason for the diminished staphylocoagulase production obtained with cultures grown in the casein hydrolysate medium based on vitamin-free Casamino acids rather than Casamino acids is obscure. Addition of different mixtures of vitamins (up to 12) gave no increase in staphylocoagulase production. Further, investigations regarding the composition and preparation of the Difco products used failed to reveal the cause of the difference in yields.

A synthetic medium for $S$. aureus 104 has not been described previously, although Marston \& Fahlberg (1960) described a synthetic medium suitable for $S$. aureus NCTC 8178. In our hands, neither $S$. aureus 104 nor NCTC 8178 produced any staphylocoagulase in this medium (data not shown). However, with the synthetic medium described here, both $S$. aureus 104 and NCTC 8178 (the latter grown with agitation) produced considerable amounts of staphylocoagulase ( 65 and $40 \mathrm{U} \mathrm{ml}^{-1}$, respectively).

Staphylocoagulase was produced optimally $\left(120 \mathrm{U} \mathrm{ml}^{-1}\right)$ in medium containing $5 \%(\mathrm{w} / \mathrm{v})$ casein hydrolysate. The $\mathrm{Mg}^{2+}$ concentration was critical for staphylocoagulase production, being optimal at 50 to $100 \mu \mathrm{M}$; higher concentrations were inhibitory. Glycerol (and glucose) concentrations higher than $0.2 \%(\mathrm{w} / \mathrm{v})$ also inhibited staphylocoagulase production. Addition of bovine serum albumin (up to $1 \%, w / v$ ), previously considered necessary to obtain high staphylocoagulase yields (Altenbern, 1966), failed to give any enhancement. For staphylocoagulase purification, the casein hydrolysate medium was chosen for bulk production. For physiological studies (particularly continuous culture studies), the synthetic medium and the casein hydrolysate medium seemed the most promising since both media are free of lipid and protein. Removal of any of the amino acids from the synthetic medium reduced the amount of staphylocoagulase produced.

In all the media listed in Table 1, staphylocoagulase production occurred only in the exponential growth phase. Optimal amounts of enzyme were obtained with an initial $\mathrm{pH}$ of $7 \cdot 4$, an incubation temperature of $35^{\circ} \mathrm{C}$ and a 1 in 10 inoculum of overnight culture.

The complex nature of the regulation of staphylocoagulase production is illustrated by Fig. 2. In agitated yeast extract medium, production of staphylocoagulase by $S$. aureus 104 reached a maximum after $1.5 \mathrm{~h}$ and then declined rapidly. If shaking was stopped $1.5 \mathrm{~h}$ after inoculation, the staphylocoagulase level still declined, but after several hours synthesis restarted. When the experiment shown in Fig. 2 was repeated in stirred fermenters, the decrease in staphylocoagulase level (from 18 to $4 \mathrm{U} \mathrm{ml}^{-1}$ ) at $300 \mathrm{rev} \cdot \mathrm{min}^{-1}$ was accompanied by a decrease in $\mathrm{pH}$ (to $\mathrm{pH} 5.5$ ). When growth continued, the $\mathrm{pH}$ rose to 8 to 8.5 and staphylo- 


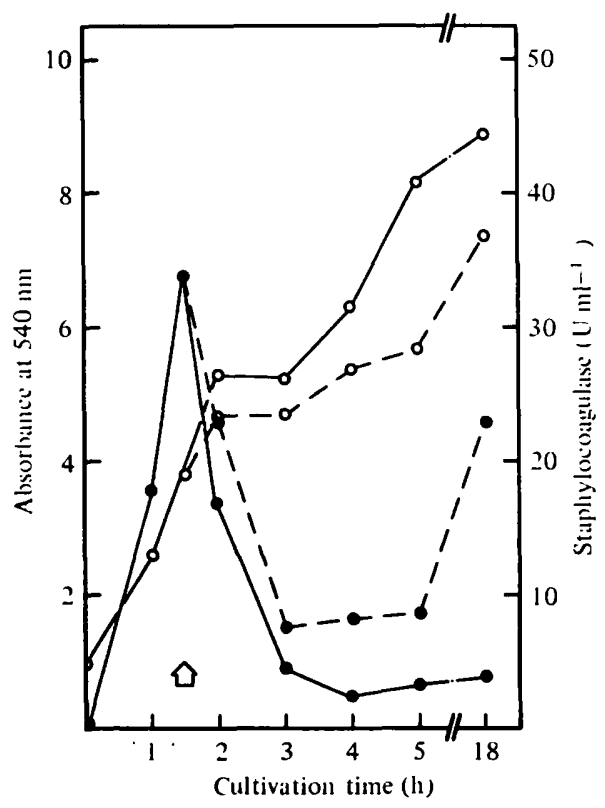

Fig. 2. Staphylocoagulase production by Staphylococcus aureus 104 as a function of the cultivation time. Four Erlenmeyer flasks $(100 \mathrm{ml})$, each containing $20 \mathrm{ml}$ yeast extract medium, were inoculated with $2 \mathrm{ml}$ overnight culture and incubated at $35^{\circ} \mathrm{C}$ and $190 \mathrm{rev}$. min $^{-1}$. After $1.5 \mathrm{~h}$, as marked by the arrow, two flasks were transferred to a non-shaking waterbath at $35^{\circ} \mathrm{C}$ and the experiment was continued. -- , Static cultures; - - , shaken cultures; $\bigcirc$, staphylocoagulase; $\bigcirc$, absorbance at $540 \mathrm{~nm}$.

Table 2. Staphylocoagulase production by Staphylococcus aureus 104

Yeast extract medium $(20 \mathrm{ml})$ was inoculated with $2 \mathrm{ml}$ overnight culture and shaken at $190 \mathrm{rev}$. $\mathrm{min}^{-1}$ at $35^{\circ} \mathrm{C}$. After $1.5 \mathrm{~h}$, the culture was centrifuged at $5000 \mathrm{~g}$ for $15 \mathrm{~min}$. The supernatant contained $27 \mathrm{U}$ staphylocoagulase $\mathrm{ml}^{-1}$. Sediment and supernatant were then incubated in various mixtures (as indicated) and staphylocoagulase production in these mixtures was determined after a further $1.5 \mathrm{~h}$.

Incubation mixture

Control: culture not centrifuged

Sediment $+20 \mathrm{ml}$ supernatant

Sediment $+20 \mathrm{ml}$ fresh yeast extract medium

$2 \mathrm{ml}$ Overnight culture $+18 \mathrm{ml}$ supernatant
Staphylocoagulase production $\left(\mathrm{U} \mathrm{ml}^{-1}\right)$

$$
\begin{array}{r}
-16 \\
-16 \\
0.5
\end{array}
$$

17

coagulase production began again, attaining $15 \mathrm{U} \mathrm{ml}^{-1}$ after overnight growth. Under conditions in which the $\mathrm{pH}$ was maintained at $7 \cdot 4$, there was little reduction in staphylocoagulase levels $\left(8 \mathrm{U} \mathrm{ml}^{-1}\right.$ at $200 \mathrm{rev}$. $\mathrm{min}^{-1}$, remaining constant during $18 \mathrm{~h}$ cultivation; $18 \mathrm{U} \mathrm{ml}^{-1}$ at $300 \mathrm{rev} . \mathrm{min}^{-1}$, decreasing during $18 \mathrm{~h}$ cultivation to $16 \mathrm{U} \mathrm{ml}^{-1}$ ). Similar observations were made by Duthie \& Haughton (1958) for $S$. aureus NCTC 8178 growing in a casein hydrolysate medium. They found that the amount of staphylocoagulase reached a maximum 80 min after inoculation, and then decreased rapidly. The maximum level of staphylocoagulase under the conditions of Fig. 2 was strongly dependent on the inoculum size. Optimal staphylocoagulase production $\left(42 \mathrm{U} \mathrm{ml}^{-1}\right)$ occurred with a 1 in 10 inoculum.

The experiment shown in Table 2 indicated that the reduction in staphylocoagulase production is probably not due to exhaustion of medium constituents or production of an inhibitory substance. Moreover, regardless of the growth phase, proteolytic activity was never demonstrated in the culture supernatants.

Similar findings were obtained when $S$. aureus 104 was subcultured in shaken flasks 


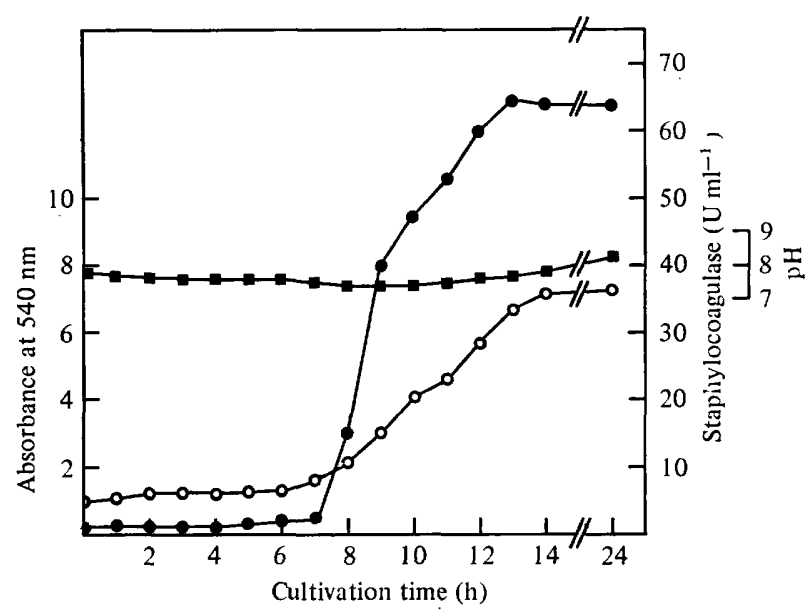

Fig. 3. Staphylocoagulase production by Staphylococcus aureus 104 as a function of the cultivation time. Thirty-two Erlenmeyer flasks $(100 \mathrm{ml})$, each containing $20 \mathrm{ml}$ casein hydrolysate medium, were inoculated with $2 \mathrm{ml}$ overnight culture and incubated at $35^{\circ} \mathrm{C}$ without agitation. Every hour, absorbance at $540 \mathrm{~nm}(\mathrm{O})$, staphylocoagulase $(\mathbf{O})$ and $\mathrm{pH}(\boldsymbol{\square})$ were determined in two flasks.

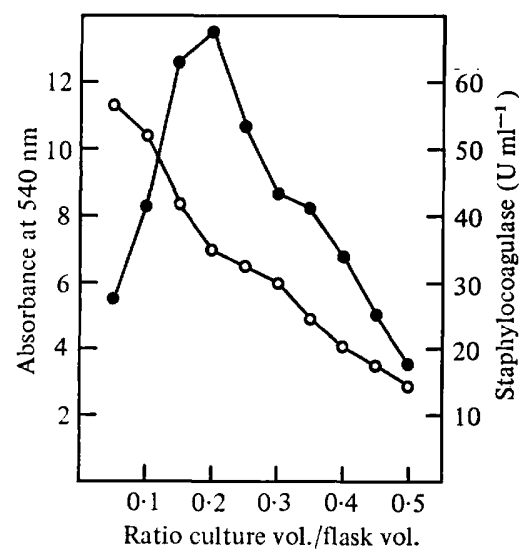

Fig. 4. Influence of the ratio culture volume/flask volume on staphylocoagulase production by Staphylococcus aureus 104 . Erlenmeyer flasks $(100 \mathrm{ml})$ containing various volumes of casein hydrolysate medium and a 1 in 10 inoculum of overnight culture were incubated at $35^{\circ} \mathrm{C}$ without agitation. After $18 \mathrm{~h}$, absorbance at $540 \mathrm{~nm}(\mathrm{O})$ and staphylocoagulase $(\odot)$ were determined.

containing casein hydrolysate or yeast extract medium. After two subcultures, production of staphylocoagulase ceased completely and remained at zero during 14 further subcultures; but when the culture was subcultured to casein hydrolysate or yeast extract medium and incubated statically, staphylocoagulase production began again and regained its full potential after 2 to 3 subcultures. When $S$. aureus 104 was subcultured up to 14 times in casein hydrolysate or yeast extract medium incubated statically, production of staphylocoagulase remained high. The loss of ability of staphylococci to produce staphylocoagulase, described by Tager (1974), is evidently dependent on the cultivation conditions.

The production of staphylocoagulase in casein hydrolysate medium at different growth phases is shown in Fig. 3. After a prolonged lag phase, rapid growth was accompanied by production of the enzyme. When growth ceased, there was no further change in staphylocoagulase level. The $\mathrm{pH}$ remained practically constant, which is an important factor in optimal staphylocoagulase production. 
That agitation and inoculum size influence staphylocoagulase production so markedly suggests that aeration efficiency is important. Thus staphylocoagulase production takes place only when the aeration efficiency is less than a critical value, as indicated by the experiment shown in Fig. 4. The maximum production is related to the final culture density, because at a medium volume/flask volume ratio higher than $0 \cdot 2$, both production of staphylocoagulase and cell density decrease, indicating that the amount of staphylocoagulase produced per cell is approximately constant.

Oxygen measurements made with a Clark electrode during growth of $S$. aureus 104 in casein hydrolysate medium without agitation revealed that in the lag phase the dissolved oxygen concentration was less than $2 \%$. Redox potential measurements (which also give an indication of the oxygen concentration) with a platinum and a calomel electrode indicated that the redox potential of the culture decreased rapidly during the first $2 \mathrm{~h}$ cultivation, from $+400 \mathrm{mV}$ to $+100 \mathrm{mV}$, and then continued to decrease steadily for the next $21 \mathrm{~h}$ to $-80 \mathrm{mV}$. Staphylocoagulase was produced at redox potentials between +40 and $+60 \mathrm{mV}$, i.e. during a period of considerable oxygen-limitation. For other extracellular enzymes (phosphatase, staphylokinase, enterotoxin A, nuclease) oxygen-limiting conditions are also necessary for high amounts of enzyme to be formed (Arvidson et al., 1976; Carpenter \& Silverman, 1976).

Although it is apparent that oxygen plays a major role in staphylocoagulase production by $S$. aureus 104 , other factors are involved, such as $\mathrm{pH}$, growth rate and nutrient-limitation, which need to be studied further. Experiments concerning the influence of these factors might usefully employ continuous culture techniques. However, the possibility remains that staphylocoagulase production by $S$. aureus 104 is a transient-state and not a steady-state phenomenon, so that continuous culture may not be applicable.

It is not clear whether staphylocoagulase is a true exo-enzyme. Indeed only low levels of the enzyme can be demonstrated in cell lysates of $S$. aureus 104 [prepared with lysostaphin, see also Altenbern (1966)], but the possibility that a high percentage of lysis occurs during growth cannot be excluded. Extracellular RNA and DNA, released during lysis, cannot be demonstrated because $S$. aureus 104 also produces high levels of a nuclease which breaks down RNA and DNA. Moreover, Blobel \& Berman (1960) demonstrated that staphylocoagulase is also located on the cell surface. Therefore growth conditions that result in unstable walls might be favourable for high levels of staphylocoagulase. The non-specific stimulatory effect of serum albumin as described by Altenbern (1966), and the influence of the $\mathrm{Mg}^{2+}$ concentration on staphylocoagulase production, indicate that the wall composition may well play an important role.

We wish to thank Dr O. N. Neijssel for helpful discussions and Professor D. W. Tempest for critically reading the manuscript.

\section{REFERENCES}

Altenbern, R. A. (1966). On the nature of albuminpromoted coagulase release by Staphylococcus aureus. Journal of Infectious Diseases 116, 593-600.

Arvidson, S., Buörklind, A., Eriksson, R. \& Holme, T. (1976). Enzymes from Staphylococcus aureus. In Continuous Culture: Applications and New Fields, vol. 6, pp. 238-250. Edited by A. C. R. Dean, D. C. Ellwood, C. G. T. Evans \& J. Melling. Chichester: Ellis Horwood.

Bas. B. M., Muller, A. D. \& Hemker, H. C. (1974). Purification and properties of staphylocoagulase. Biochimica et biophysica acta 379, 164-171.

Blobel, H. \& Berman, D. T. (1960). Serologic studies of purified staphylococcal coagulase with special reference to fluorescence microscopy. Journal of Immunology 85, 244-249.

Blobel, H., Berman, D. T. \& Simon, J. (1960). Purification of staphylococcal coagulase. Journal of Bacteriology 79, 807-815.

Carpenter, D. F. \& Silverman, G. J. (1976). Synthesis of staphylococcal enterotoxin $A$ and nuclease under controlled fermentor conditions. $A p$ plied and Environmental Microbiology 31, 243-248. CoOper, C. M., Fernstrom, G. A. \& Miller, S. A. (1944). Performance of agitated gas-liquid contactors. Industrial and Engineering Chemistry 36, 504-509. 
Duthie, E. S. \& Haughton, G. (1958). Purification of free staphylococcal coagulase. Biochemical Journal 70, 125-134.

Evans, C. G. T., Herbert, D. \& Tempest, D. W. (1970). The continuous cultivation of microorganisms. II. Construction of a chemostat. Methods in Microbiology 2, 277-328.

Fahlberg, W. J. \& Marston, J. (1960). Coagulase production by Staphylococcus aureus. I. Factors influencing coagulase production. Journal of Infectious Diseases 106, 111-115.

Hemker, H. C., Bas, B. M. \& Muller, A. D. (1975). Activation of a pro-enzyme by a stoichiometric reaction with another protein. The reaction between prothrombin and staphylocoagulase. Biochimica et biophysica acta 379, 180-188.

JACHERTS, D. (1956). Zur Reindarstellung der Staphylokokken Coagulase. Zeitschrift für Hygiene, Medizinische Mikrobiologie, Immunologie und Virologie 142, 213-218.

JelJaszewiCZ, J. (1958). Studies on staphylococcal coagulases. Acta microbiologica polonia 7, 17-34.

MARSTON, J. \& FAHLBERG, J. (1960). Coagulase production by Staphylococcus aureus. II. Growth and coagulase production in complex and chemically defined mediums-comparison of chemically defined mediums. Journal of Infectious Diseases 106, 116-122.
Murray, M. \& Ghodes, P. (1960). Purification of the staphylococcal coagulase. Biochimica et biophysica acta 40, 518-522.

Siwecka, M. \& Jeljaszewicz, J. (1968). Purification of staphylocoagulase and some of its properties. Zentralblatt für Bakteriologie, Parasitenkunde, Infektionskrankheiten und Hygiene (Abteilung I, Originale A) 208, 385-394.

Soulier, J. P., Lewi, S., Panty, A. M. \& ProuWartelle, O. (1967). Préparation, concentration et étalonnage de la staphylocoagulase. Revue française d'études cliniques et biologiques 12, 544558.

Stutzenberger, F. J. \& San Clemente, C. L. (1968). Production and purification of staphylococcic coagulase in a semi-defined medium. American Journal of Veterinary Research 29, 1109-1116.

TAGER, M. (1948). Concentration, partial purification, properties and nature of staphylocoagulase. Journal of Biological Medicine 20, 487-501.

TAGER, M. (1974). Current views on the mechanism of coagulase action in blood clotting. Annals of the New York Academy of Sciences 236, 277-291.

Zolli, Z. \& San Clemente, C. L. (1963). Purification and characterization of staphylocoagulase. Journal of Bacteriology 86, 527-535. 